\title{
Biotechnological Approaches in Management of Viral Diseases of Horticulture Crops
}

\author{
Sheemal Sugandha Sharma, Shalini Verma* and Anil Handa
}

Department of Plant Pathology, Dr. Yashwant Singh Parmar University of Horticulture and Forestry, Nauni, Solan (H.P.) - 173230, India

*Corresponding author

\begin{tabular}{|l|}
\hline Ke y w o r d s \\
Management \\
strategies, Virus, \\
Biotechnology, \\
Gene silencing, \\
CRISPR
\end{tabular}

\section{A B S T R A C T}

Viral diseases are one of the major factors threatening crop production worldwide. It is estimated that about 15 percent of global crop production is lost due to various plant diseases, and phytopathogenic viruses are thought to cause more than one third of plant diseases. Viruses such as TYLCV, PRSV, CMV, BBTV are some major virus epidemics which cause heavy losses in horticultural crops. Management of plant virus diseases have acquired great importance in the realm of Plant Pathology and call for effective management against them. Although pesticides are commonly used to reduce viral vector populations, chemical treatments cannot directly limit viral infections. A number of indirect control measures have been developed with an aim to avoid the pathogen or minimize their impact on crop yield. As more complex and probably more durable resistance can be more difficult to establish and certainly more difficult to achieve by conventional approach. Thus, biotechnology represents the latest front in the ongoing scientific progress of this century. Gene silencing (GS) is involved in the down regulation of specific genes, and probably evolved as a genetic defense system against viruses and invading nucleic acids. The discovery of mechanism that suppress the gene activity in plants has extended the horizon on the research on control of gene expression. Currently there are several routes of GS identified in plants such as Post transcriptional gene silencing (PTGS), RNA interference (RNAi) and Virus induced gene silencing (VIGS). Recent investigations suggest that antiviral RNA silencing is the most prevalent defense strategy in plants. Also CRISPR (Clustered Regularly Interspaced Palindromic repeats) Cas 9 is a recent breakthrough in gene editing technology. The integration of CRISPR has facilitated the production of cultivar with heritable resistance to viral diseases.

\section{Introduction}

Management of plant virus diseases is a matter of vital importance and concern to the farmer, horticulturist, forester and gardener. It is well established that the virus and viroid diseases in different crops cause enormous losses in terms of quantity and quality of products (Sastry, 2013). Because of the serious losses they cause to agriculture and horticulture, virus/viroid diseases have acquired great importance in the realm of Plant Pathology and call for effective management measures against them. These 
diseases are not amenable to control by direct methods. Unlike fungicides and bactericides, no commercial viricides have yet been developed. However, a number of indirect control measures for different crop plantvirus/viroid pathosystems suitable to varied agro ecosystems have been developed with an aim to avoid the pathogen or to minimize their impact on crop yields (Thresh, 2003; Thresh, 2006). Because of the yield losses caused by viruses, their detection, mode of transmission between plants and control have been the subject of a vast number of scientific investigations (Jones et al., 2010; Ferriol et al., 2013; Juarez et al., 2013).

\section{Need for diagnosis of plant virus and viroid diseases}

An effective and applicable virus management strategy requires an accurate diagnosis and understanding the life and disease cycle of etiological agents. Recent developments in molecular techniques have revolutionized the field of diagnostics in agriculture (Sastry, 2013). High detectability, specificity, sensitivity and accuracy supported with simplicity, amenable to automation and low cost are the main characteristics of an ideal diagnostic strategy.

\section{Conventional approaches to manage plant viral diseases}

Many indigenous methods have been tried to manage virus/viroid diseases by breaking the disease cycle at inoculum source, and interfering with transmission or infection. The entire range of methods aimed at the control of plant virus diseases is generally divisible into the following distinct categories:

\section{Disadvantages of conventional methods}

In case of meristem tip culture low survival rate and regeneration time for explants may be long, Conventional methods are time consuming.

They have low accuracy rate and are inefficient.

Lack of proper quarantine measures for the introduced plant materials has resulted in the introduction of some very highly devastative virus diseases from one country to another, and has proven to be catastrophic. This has resulted into increased cost of food material. A good example is Citrus Tristeza Virus (CTV).

Moving on to the biotechnological approaches as they are the only means when traditional methods have failed hence capable of bringing about a revolution in the agricultural sciences.

It is estimated that about 15 percent of global crop production is lost due to various plant diseases and phytopathogenic viruses are thought to cause more than one third of plant diseases. Mitigation of these losses by improved viral resistance is a worthwhile strategy to meet global yield targets.

Arguably, the utilization of genetic resistance in crops is the most sustainable approach for the control of virus infections, other methods, such as pesticides to control insect vectors or manual inspection and removal of infected plants, are costly, laborious and often ineffective.

\section{Biotechnological approaches to manage plant viral disease}

Protection of crop cultivar against existing pest and disease as well as improvement of crop cultivar from higher productivity standpoint is a major challenge. Lack of disease resistant varieties of crops is the major reason farmers are facing loss in agriculture 
production. Plant breeding for pests, disease resistance and higher productivity helps in the development of disease resistant crop cultivars safeguarding food security. Different genome editing and advanced molecular techniques with transgenic plants are integrated with plant breeding to achieve improved crop cultivar with enhanced resistance to pest and diseases, termed as resistance breeding. Transgenic technology allows plant breeder to cross crop species introducing genes from nonrelated plants and other organisms into the crop plants (Melchers and Stuiver, 2000).

\section{Gene silencing}

The discovery of mechanisms that suppress gene activity in plants has extended the horizon for research on control of gene expression (Mansoor et al., 2006). Gene silencing (GS) is defined as a molecular process involved in the down regulation of specific genes, and probably evolved as a genetic defense system against viruses and invading nucleic acids(Waterhouse et al., 2001). Currently, there are several routes of GS identified in plants, such as: posttranscriptional gene silencing (PTGS) and transcriptional gene silencing (Vaucheret and Fagard, 2001).

\section{Transcriptional Gene Silencing (TGS)}

DNA methylation and chromatin remodeling play a major role in transcriptional gene silencing (TGS), blocking gene expression (Waterhouse et al., 2001). In TGS, silenced transgenes coding regions and promoters are densely methylated (Kooter et al., 1999). It is also proposed that the increase in DNA methylation possibly induces formation of heterochromatin, which is associated to TGS. DNA methylation promotes protein binding that recognizes methylated cytosine, leading to chromatin remodeling, thus avoiding the binding of transcription fact. Heterochromatin can be defined as condensate chromosomal regions, which are densely stained and known for genetic inactivity. Methylation, acetylation, phosphorilation and ubiquitination of core histones $\mathrm{H} 2 \mathrm{~A}, \mathrm{H} 2 \mathrm{~B}, \mathrm{H} 3$ and $\mathrm{H} 4$ are implicated in gene regulation (Lippman and Martienssen, 2004). These chemical modifications within histones alter the packing state of DNA between euchromatin (active DNA) and heterochromatin (inactive DNA). Histone acetylation is one factor that can destabilize chromatin structure by altering the charge composition within chromatin. Chemical alterations within histone tails may function as signals for chromatin remodeling complexes, which are responsible for regulating the accessibility of the cells transcriptional machinery to the DNA (Alberts et al., 2002). At least in plants there is a direct link between DNA methylation and histone methylation suggesting that they play a common role in transcriptional gene silencing (Lippman and Martienssen, 2004).

\section{Post-Transcriptional Gene Silencing (PTGS)}

The ability of exogenous or sometimes endogenous RNA to suppress the expression of the gene which corresponds to the m-RNA sequence (Vaucheret et al., 2001).

It includes:

Antisense technology

RNA Interference (RNAi)

Virus-induced gene silencing (VIGS)

\section{Antisense technology}

A conventional definition of antisense refers to the laboratory manipulation and/or modification of DNA or RNA so that its components (nucleotides) form a complimentary copy of normal, or "sense," 
messenger RNA (mRNA). The binding or hybridization of antisense nucleic acid sequences to a specific mRNA target will, through a number of different mechanisms, interrupt normal cellular processing of the genetic message of a gene. This interruption, sometimes referred to as "knock-down" or "knock-out" depending upon whether or not the message is either partially or completely eliminated, allows researchers to determine the function of that gene. Three types of antimRNA strategies can be distinguished.

Firstly, the use of single-stranded antisenseoligonucleotides; secondly, the triggering of RNA cleavage through catalytically active oligonucleotides referred to as ribozymes; and thirdly, RNA interference induced by small interfering RNA molecule.

The overall goal in introducing an antisense agent into cells either in vitro or in vivo is to suppress or completely block the production of the gene product. This means that at some point in the transition from DNA sequence to amino acid sequence, the normal transcription and translation apparatus must be affected. Antisense refers to short DNA or RNA sequences, termed oligonucleotides, which are designed to be complementary to a specific gene sequence. The goal is to alter specific gene expression resulting from the binding of the antisense oligonucleotide to unique gene sequences (Neckers and Whitesell, 1993)

Antisense technology is supposed to prevent protein production from a targeted gene. The exact mechanism by which this occurs remains uncertain. Proposed mechanisms include triplex formation, blocking RNA splicing, preventing transport of the mRNA antisense complex into the cytoplasm, increasing RNA degradation, or blocking the initiation of translation. Initially, cellular nucleases dramatically reduced the effectiveness of antisense oligonucleotides by rapidly degrading these molecules after administration. These obstacles can be overcome in applications utilizing synthetic oligonucleotides by altering the nature of the phosphodiester bond by replacing oxygen with sulfur. Such modified oligonucleotides are termed phosphorothionates.

\section{RNA interference}

RNA silencing is an evolutionarily conserved mechanism in eukaryotes. It is induced by double-stranded RNA (dsRNA) or hairpin structured RNA (hpRNA), involving common factors including Dicer or Dicer-like (DCL) and Argonaute (AGO) family proteins (Baulcombe, 2004). In the basic RNA silencing pathway, dsRNA or hpRNA is processed by a Dicer or DCL protein into 20 to 24 nucleotide (nt) small RNA (sRNA) duplex with 2-nt 3' overhangs at both ends. One strand of the sRNA duplex is incorporated into an AGO forming an RNAinduced silencing complex (RISC).

The sRNA molecule guides the RISC to the complementary region of single-stranded RNA, and the AGO protein then cleave the RNA at the nucleotides corresponding to the central region (usually nt. 10-11) of the sRNA (Hannon, 2002). The RNA silencing pathway has greatly diversified in plants to cope with different functional requirements. According to the source of dsRNA or hpRNA precursor and the functional target of sRNAs, RNA silencing in plants can be classified into 2 overlapping but functionally distinct pathways:

MicroRNA (miRNA) pathway, Small interfering RNA (siRNA) pathway

Associated with the diversification of RNA silencing pathways, plants have evolved multiple RNA silencing factors. 


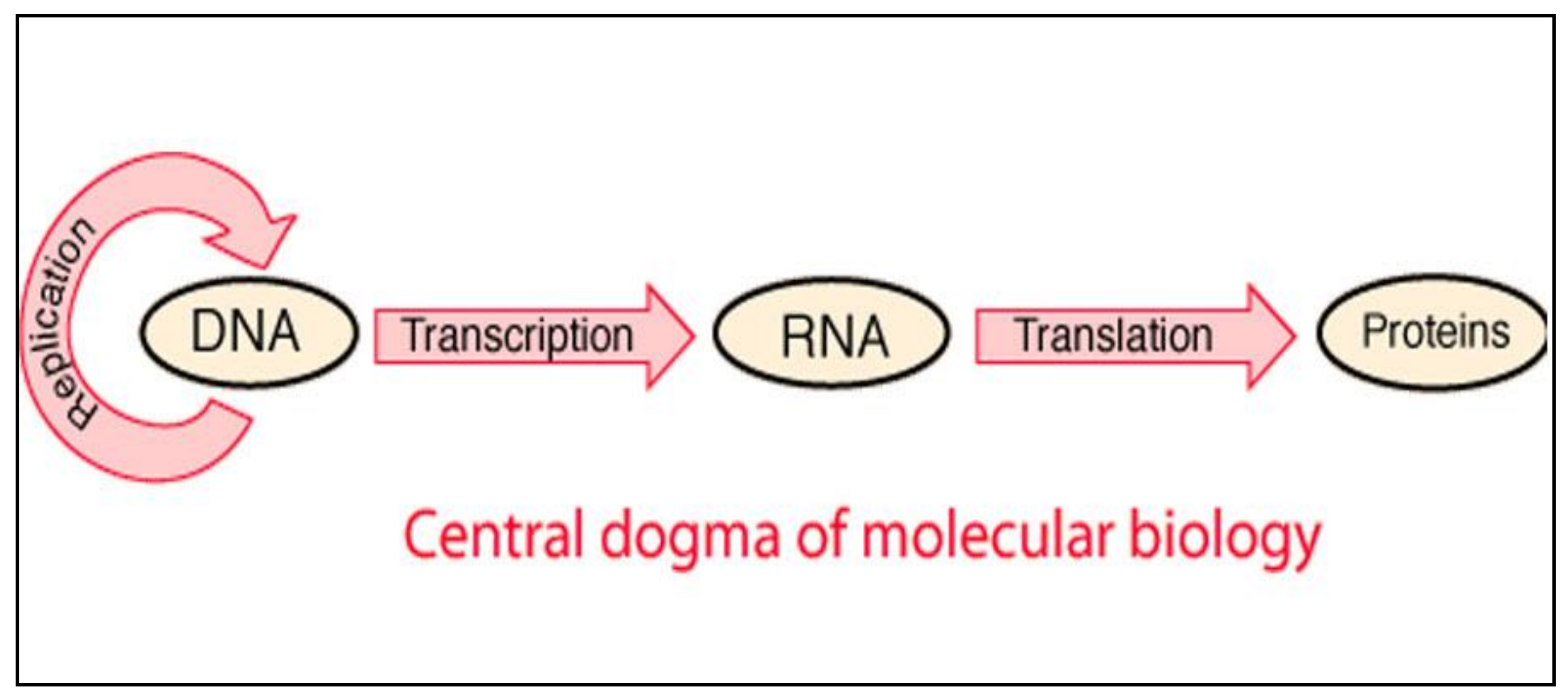

\section{Chromatin Remodelling}

DNA methylation

Histone methylation (Lysine 9)

(inc) Histone methylation (Lysine 4)

Aet Histone acctylation

A Histone phosphorylation

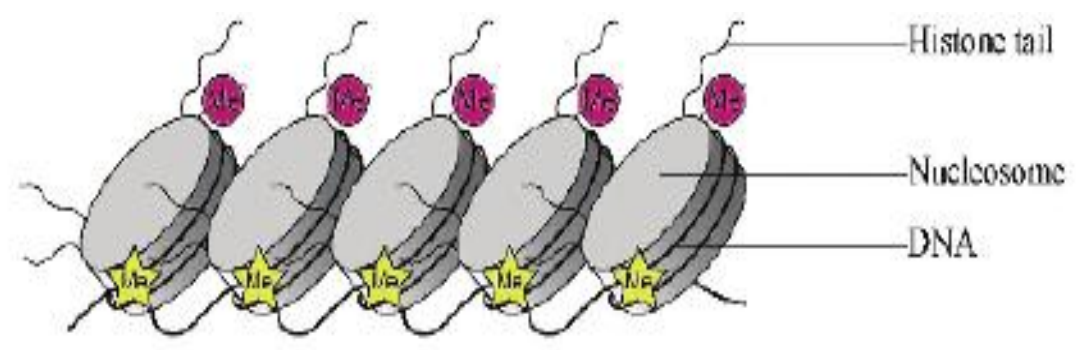

\section{Condensed State: Gene silencing}

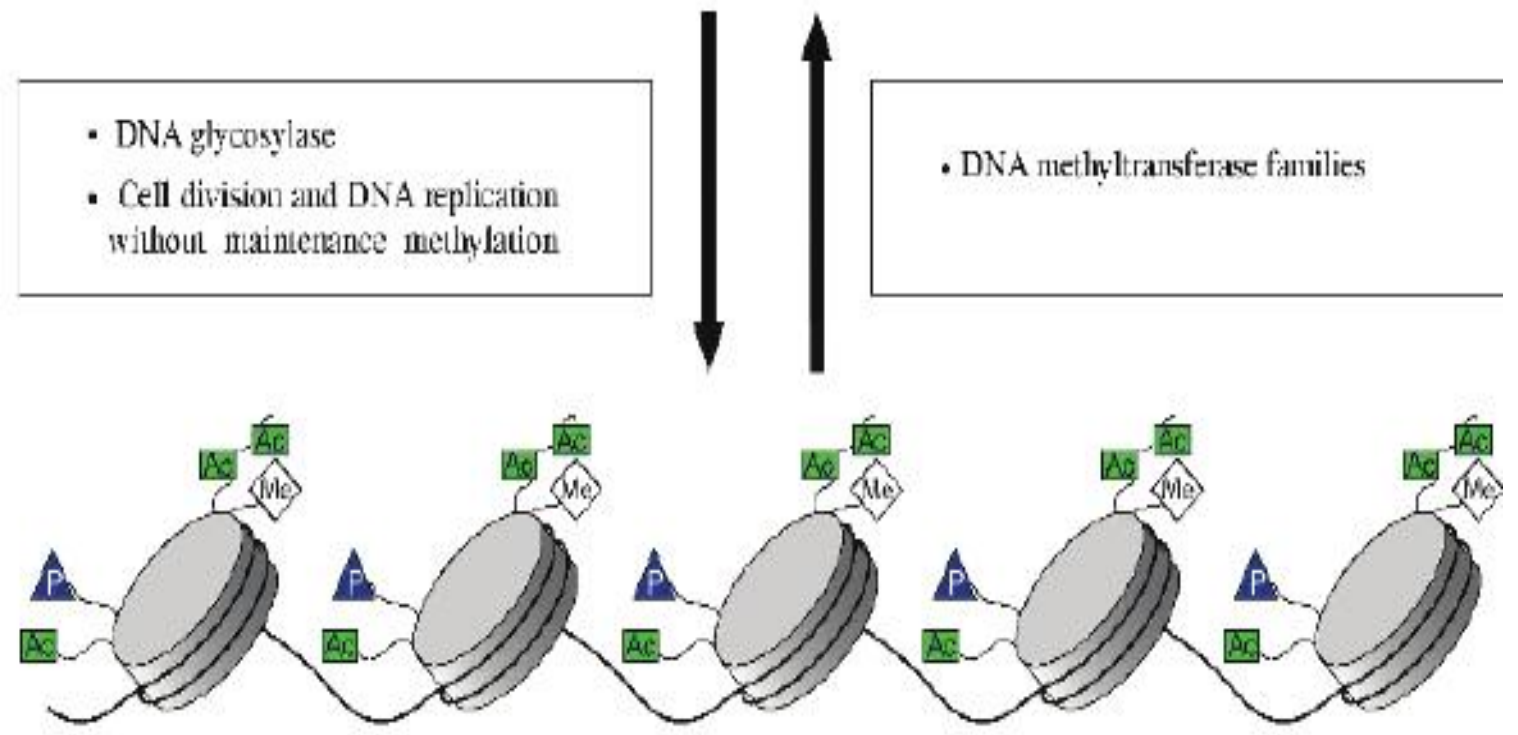

Decondensed state: Possible gene expression 
-) promotor inactive

-) promotor methylated

-) chromatin remodelling

-) frequently meiotically heritable

-)both transgene and endogenous

genes are methylated

-) non symmetrical methylation

(non CG or CNG) $\rightarrow$ hallmark of

RNA directed DNA methylation.
-) transcribed, but no full transcript found

-) coding region methylated

-) not dependent on ongoing

translation

-) fully reversible during meioses

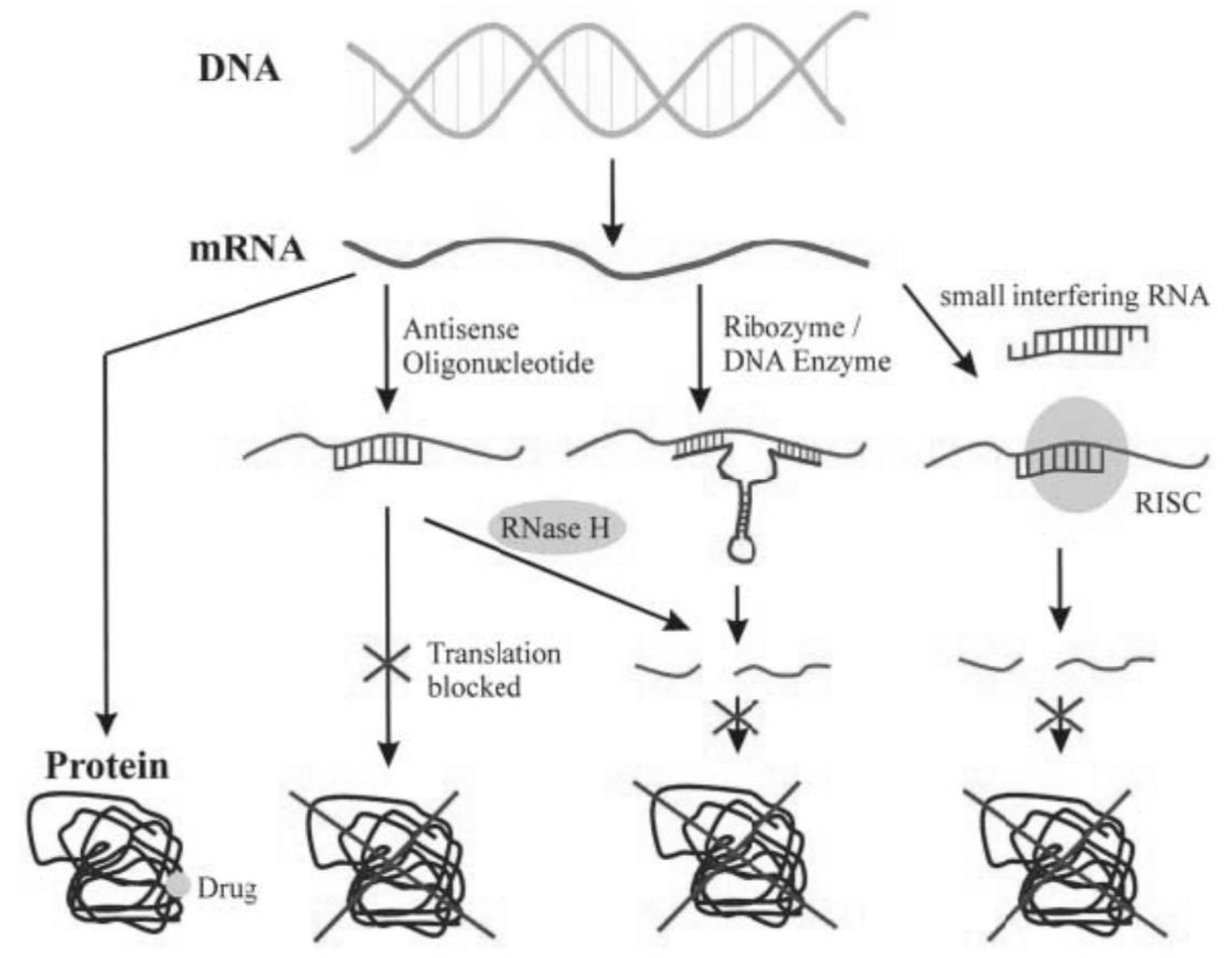




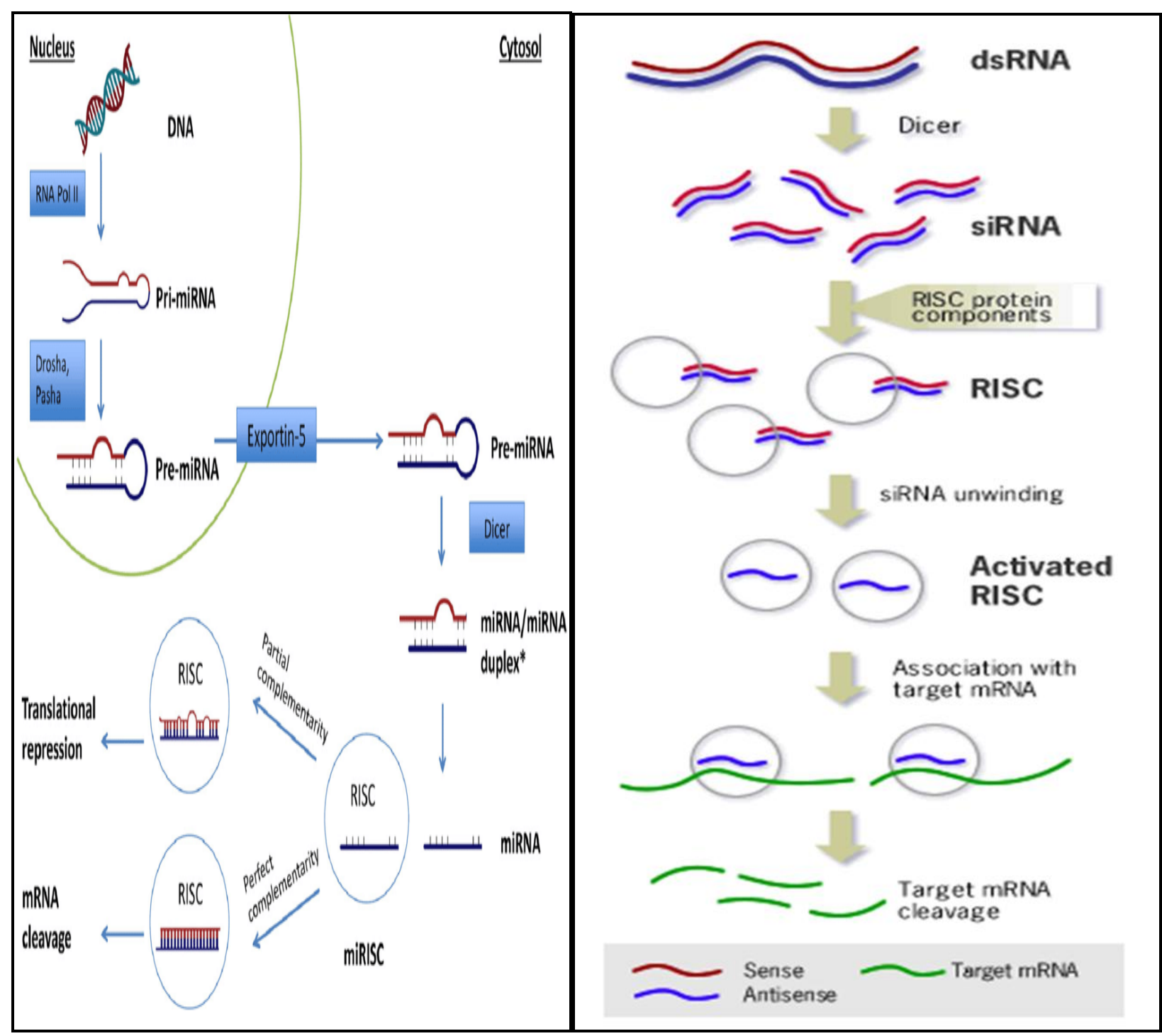

MicroRNA (miRNA) pathway Small interfering RNA (siRNA) pathway

\section{VIGS Mechanism}

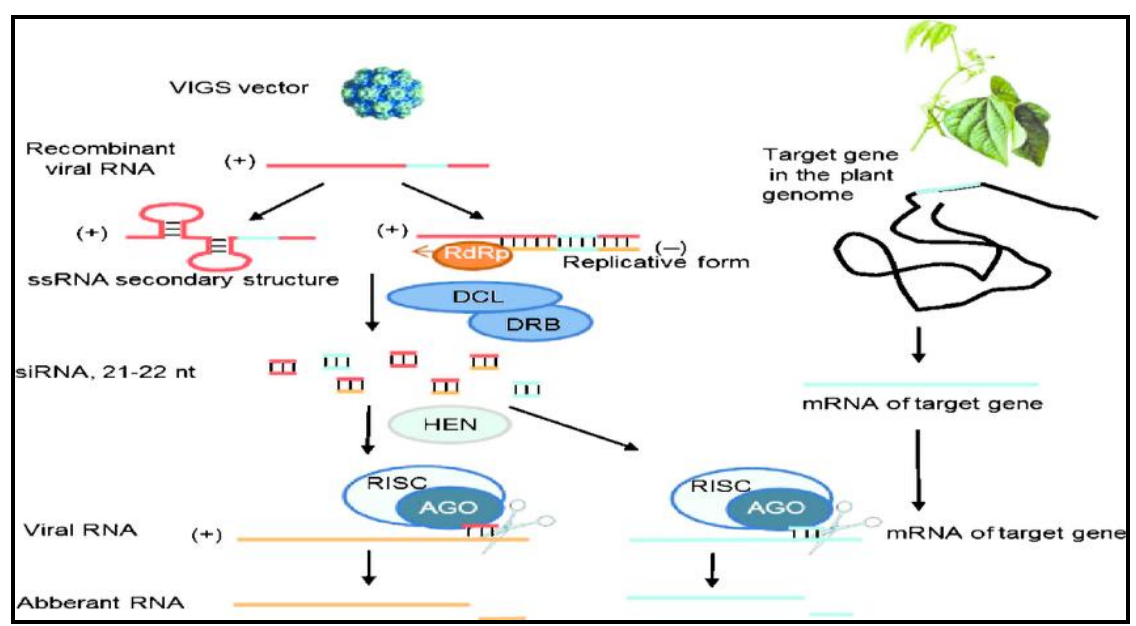




\section{Working mechanism of CRISPR}

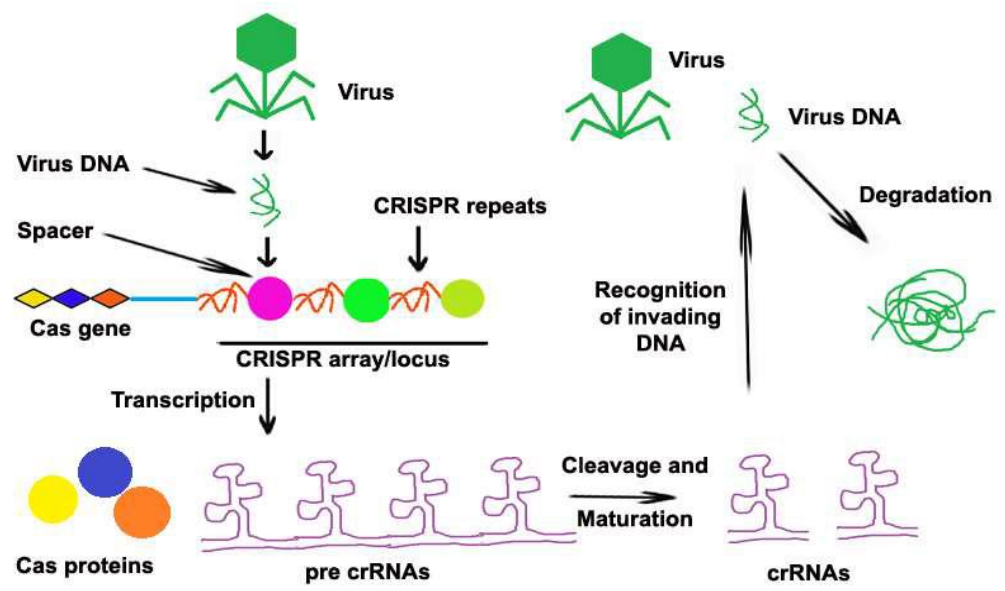

eBikalGhimire

\begin{tabular}{|l|l|l|l|}
\hline Crop & Virus & Yield loss estimate & Morphological symptoms \\
\hline Tomato & $\begin{array}{l}\text { Tomato yellow } \\
\text { leaf curl virus } \\
\text { (TYLCV) }\end{array}$ & $100 \%$ & \\
\hline Papaya & $\begin{array}{l}\text { Papaya ring spot } \\
\text { virus (PRSV) }\end{array}$ & $>80 \%$ & \\
\hline Banana & $\begin{array}{l}\text { Banana bunchy } \\
\text { top virus (BBTV) }\end{array}$ & $85 \%$ & \\
\hline Potato & $\begin{array}{l}\text { (Potato Virus X) } \\
\text { PVX } \\
\text { (Potato Virus Y) } \\
\text { PVY }\end{array}$ & $85 \%$ & \\
\hline
\end{tabular}

(Dasgupta, 2003) 
Need for diagnosis of plant virus and viroid diseases

\begin{tabular}{|l|l|l|l|l|}
\hline Disease & Category & Major hosts & Vector & Geographic distribution \\
\hline $\begin{array}{l}\text { Lettuce } \\
\text { infectious } \\
\text { yellow virus } \\
\text { (LIYV) }\end{array}$ & Emerging & Lettuce & Bemisiatabaci & USA \\
\hline $\begin{array}{l}\text { Citrus tristeza } \\
\text { virus (CTV) }\end{array}$ & Emerging & Citrus & $\begin{array}{l}\text { Several aphid } \\
\text { species }\end{array}$ & Worldwide \\
\hline
\end{tabular}

\begin{tabular}{|l|l|l|l|l|}
\hline $\begin{array}{l}\text { Tomato } \\
\text { spotted wilt } \\
\text { virus } \text { (TSWV) }\end{array}$ & Re-emerging & $\begin{array}{l}\text { ornamentals } \\
\text { / vegetables }\end{array}$ & Thrips & Worldwide \\
\hline $\begin{array}{l}\text { Tomato yellow } \\
\text { leaf curl virus } \\
\text { (TYLCV) }\end{array}$ & Emerging & tomato & Bemisiaspp. & Widespread \\
\hline
\end{tabular}

Conventional approaches to manage plant viral diseases

\begin{tabular}{|l|l|l|}
\hline 1. & Avoidan & \multicolumn{1}{c|}{ PHYTOSANITATION } \\
ce & $\begin{array}{l}\text { The new plantings should not be located near old plantings. For example, new tomato, } \\
\text { capsicum, leafy crops or cucurbits or any other vegetables should not be grown nearby } \\
\text { old fields having the same or another susceptible crop harboring virus diseases. }\end{array}$ \\
\hline 2. & Roguing & $\begin{array}{l}\text { Bunchy top of banana caused by Banana bunchy top virus can be managed only if } \\
\text { affected plants are identified frequently, removed from plantations, and destroyed. }\end{array}$ \\
\hline
\end{tabular}

(Mackie et al., 2002)

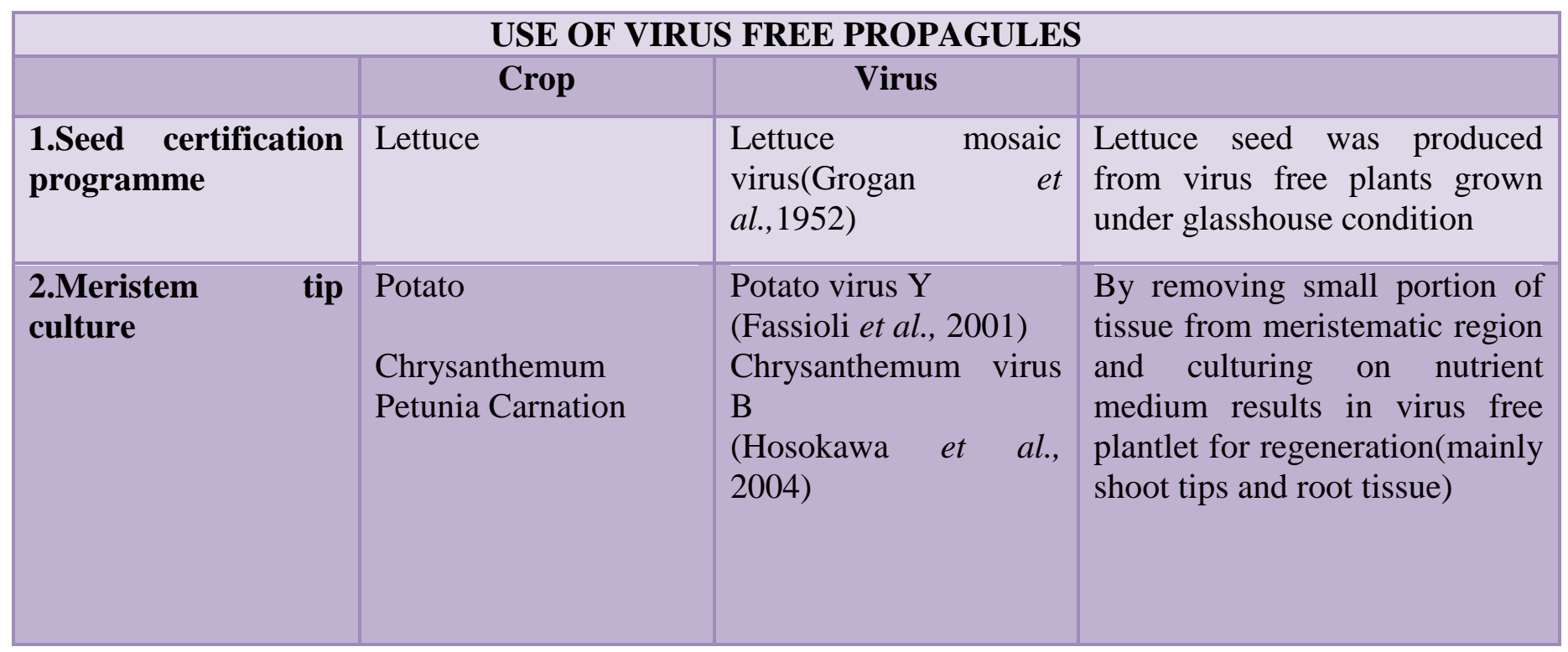




\begin{tabular}{|c|c|c|c|}
\hline \multicolumn{4}{|c|}{ VARIATION OF CROP } \\
\hline Crop protected & Virus & Barrier crop & Country \\
\hline Potato & $\begin{array}{l}\text { Potato leafroll virus } \\
\text { (PLRV) }\end{array}$ & Wheat, mustard & Bangladesh \\
\hline Tomato & $\begin{array}{c}\text { Tomato yellow leaf curl } \\
\text { virus (TYLCV) }\end{array}$ & Maize & India \\
\hline French bean & $\begin{array}{c}\text { Bean common mosaic } \\
\text { virus (BCMV) }\end{array}$ & Sorghum, maize & India \\
\hline Cowpea & $\begin{array}{c}\text { Cowpea banding mosaic } \\
\text { virus }(\mathrm{CpBMV})\end{array}$ & Pearl millet, maize & India \\
\hline
\end{tabular}

(Mannan, 2003)

\begin{tabular}{|l|l|l|}
\hline \multicolumn{2}{|c|}{ Crop } & \multicolumn{1}{c|}{ Virus } \\
\hline Citrus & $\begin{array}{l}\text { Citrus tristeza virus(CTV) } \\
\text { Banana bunchy top virus (BBTV) }\end{array}$ & Capoor and Rao, 1967 \\
\hline Banana & $\begin{array}{l}\text { Apple mosaic virus (ApMV), } \\
\text { Apple chlorotic leaf spot virus } \\
\text { (ACLSV) }\end{array}$ & Thomsen, 1975 \\
\hline Papple & Papaya ring spot virus (PRSV) & Wang et al., 1987 \\
\hline
\end{tabular}

\begin{tabular}{|c|c|}
\hline \multicolumn{2}{|r|}{ VECTOR CONTROL } \\
\hline Insecticides & $\begin{array}{l}\text { Pyrethroid application gave maximum control of aphid vectors Macrosiphum } \\
\text { euphorbiae and Myzus persicae halved the incidence of Potato virus } Y \text { (PVY). }\end{array}$ \\
\hline $\begin{array}{l}\text { Control of } \\
\text { nematode vectors }\end{array}$ & $\begin{array}{l}\text { 1,2-dibromo-3-chloropropane (DBCP) for nematode control are most effective in } \\
\text { case of against Xiphinema index which causes Grapevine Fan leaf virus (GFLV). }\end{array}$ \\
\hline $\begin{array}{l}\text { Soil sterilants and } \\
\text { disinfectants }\end{array}$ & $\begin{array}{l}\text { Benomyl and ribavirin to be effective in reducing Lettuce big vein associated virus } \\
\text { (LBVaV). }\end{array}$ \\
\hline Role of botanicals & $\begin{array}{l}\text { Clerodendrum aculeatum against Papaya ring spot virus (PRSV) infection in } \\
\text { papaya - no virus symptoms were noticed up to } 6 \text { months after inoculation. }\end{array}$ \\
\hline
\end{tabular}

\begin{tabular}{|l|l|l|}
\hline \multicolumn{1}{|c|}{ QUARANTINE } \\
\hline Crop & Virus intercepted & Source of country \\
\hline 1. Beans & Tomato black ring virus (TBRV) & CIAT, Columbia \\
\hline 3. Broad bean & $\begin{array}{l}\text { Bean yellow mosaic virus (BYMV) } \\
\text { Pea seed-borne mosaic virus } \text { (PSBMV) }\end{array}$ & $\begin{array}{l}\text { Spain, Syria } \\
\text { Bulgaria }\end{array}$ \\
\hline 4. Banana & $\begin{array}{l}\text { Alfalfa mosaic virus(AMV) } \\
\text { Cowpea aphid borne mosaic virus (CABMV) }\end{array}$ & $\begin{array}{l}\text { IITA, Nigeria } \\
\text { USA }\end{array}$ \\
\hline $\begin{array}{l}\text { Banana bunchy top virus } \text { (BBTV) } \\
\text { Banana Bract mosaic virus } \text { (BBrMV) }\end{array}$ & $\begin{array}{l}\text { India (Assam, Kerala, West Bengal) } \\
\text { India (Maharashtra, Gujarat) }\end{array}$ \\
\hline
\end{tabular}




\section{INTEGRATED APPROACH}

\begin{tabular}{|l|l|}
\hline Crop & Virus \\
\hline Tomato & Tomato leaf curl virus (TLCV) \\
\hline Sweet potato & $\begin{array}{l}\text { Sweet potato virus disease(SPVD), Whitefly-borne Sweet potato chlorotic } \\
\text { Stuntvirus } \text { (SPCSV), Aphid-borne Sweet potato feathery mottle virus } \\
\text { (SPFMV) }\end{array}$ \\
\hline Lettuce & Olpidium brassicae Lettuce big vein disease (LBVD) \\
\hline
\end{tabular}

Virus Induced Gene Silencing (VIGS)

Virus-induced gene silencing (VIGS) is one of the reverse genetics tools for analysis of gene function that uses viral vectors carrying a target gene fragment to produce dsRNA which trigger RNA-mediated gene silencing. There are a number of viruses which have been modified to silence the gene of interest effectively with a sequence-specific manner. Therefore, different types of methodologies have been advanced and modified for VIGS approach. Virus-derived inoculations are performed on host plants using different methods such as agro-infiltration and in vitro transcriptions. VIGS has many advantages compared to other loss of- gene function approaches. The approach provides the generation of rapid phenotype and no need for plant transformation. The cost of VIGS experiment is relatively low, and large-scale analysis of screening studies can be achieved by the VIGS. However, there are still limitations of VIGS to be overcome. Nowadays, many virus-derived vectors are optimized to silence more than one host plant such as Tobacco rattle virus (TRV)-derived viral vectors which are used for Arabidopsis and Nicotiana benthamiana. By development of viral silencing systems monocot plants can also be targeted as silencing host in addition to dicotyledonous plants. For instance, Barley stripe mosaic virus (BSMV)-mediated VIGS allows silencing of barley and wheat genes. Here we summarize current protocols and recent modified viral systems to lead silencing of genes in different host species (Kammen, 1997).

\section{Clustered regularly Interspaced short Palindromic repeats (CRISPR-Cas9)}

Gene editing and gene manipulation has always been an interesting topic for research works in molecular biology and plant breeding. Gene regulation is an important aspect for regulating and controlling the expression of specific genes to obtain desirable traits and characters in an organism and has high use in breeding of disease resistant and higher yielding cultivars. In plant breeding, gene editing is highly used to produce transgenic plants to introduce new resistant genes against crop pests and diseases. Production of transgenic plants for plant breeding with gene editing technology uses all the available genetic variation without any limitation of natural cross barriers resulting in plants that are not producible by conventional breeding methods. Various approaches for gene editing and gene manipulation serve as important tools for molecular biologists and plant breeders to integrate the essential genes in genomes of important crops (Kumar and Jain, 2014). The principle behind gene editing consists of binding domain and effector domain. Binding domain helps in the recognition and binding of sequence specific DNA while effector domain helps in the cleavage of DNA at target site and regulates transcription. In a CRISPR/Cas9 system, CRISPR locus or array are located on the genome and consists of hypervariable spacers acquired from bacteriophage virus or plasmid DNA. Cas genes are located upstream of CRISPR loci and encodes for Cas protein for defense of 
invasive genetic materials (Bhaya et al., 2011). CRIPSR/Cas9 system as an adaptive immune system possessed by many bacteria works in series of steps. At first, CRISPR containing organisms recognize foreign nucleic acid and acquire small fragments of DNA from invading bacteriophages and plasmids. Then the host incorporates the acquired fragments into its CRISPR locus as spacers between short DNA repeats. A short stretch of conserved nucleotides, Protospacer Adjacent Motifs (PAMS) act as recognition motif for the acquisition of DNA fragment into the spacer (Kumar and Jain, 2014). The expression of Cas proteins then transcribes the spacers acquired CRISPR to form pre CRIPSR RNAs (precrRNAs) which after cleavage and maturation of pre crRNAs results into CRISPR RNAs (crRNAs). These crRNAs contains spacer sequence from previous foreign nucleic acid that helps in the recognition and cleavage of invading genome, which matches with the spacer sequence and helps to protect the host cells (Wang et al., 2016). This unique ability of bacteria to acquire invading or foreign DNA fragments and utilize them to degrade further invading DNA or RNA sequences confers CRISPR/Cas9 system as an acquired and heritable defense system.

CRISPR/Cas9 system can be used to create disease resistance in plants through guide RNA (sgRNA) technology. sgRNA is formed by the fusion of crRNA and trans-encoded CRISPR RNA (tracrRNA) (Qi et al., 2013). Cas9 together with sgRNA forms RNA guided nuclease that regulates the sequence specific cleavage and editing in the target genome (Jinek et al., 2012). The site specific cleavage action of sgRNA-Cas9 complex is defined by pre designed sequences in guide RNA which has $\sim 20$ base pairs that are complementary to target DNA and helps in the binding of guide RNA to strands of target DNA (Kumar and Jain, 2014; Wang et al.,
2016). With use of sgRNA as binding domain, specific sequence of bacterial DNA can be edited and invading foreign DNA such as phages can be cleaved by RNA guided nuclease in a sequence specific manner (Chaparro-Garcia et al., 2015). Guide RNA binds to DNA and the pre-designed sequences in RNA guides Cas9 enzyme to cut the DNA strands at right locations. Cutting of DNA proceeds with removal and addition of required sequences into the target DNA (Wang et al., 2016). This technique can be explored to create resistance to specific disease in plants through delivery of sgRNA and Cas9 into target cells for gene transformation. Different methods are used for delivery of sgRNA and Cas9 into plants cells like electroporation, via plasmids, Agrobacterium mediated transformation, shotgun methods and particle bombardment.

Baltes et al., (2015) and Ji et al., (2015) explained the use of CRISPR/Cas9 technique for protection of plants against geminiviruses. Ali et al., (2015) performed experiment to demonstrate the efficacy of CRISPR/Cas9 against tomato yellow leaf curl virus (TYLCV) in Nicotiana benthamiana plants and their results exhibited profound evidence of interference against viral DNA by use of guide RNA mediated through Agrobacterium tumefaciens and also engineered tobacco rattle virus (TRV) with sgRNA specific for TYLCV into Agrobacterium tumefaciens and infiltrated it into plant.

In conclusion, current agricultural technology needs more and more molecular tools to reduce current crop loss and feed extra mouths, which according to a recent estimate by the FAO (Food and Agriculture Organization) will increase by two billion over the next 30 years. The resistance technologies described above describes such powerful innovation. If judiciously used, these technologies may go a long way to 
narrow the gap through production of diseasevirus resistant, nutritionally rich and toxicfree crops. The cost effectiveness is always a big question. Fortunately, the situation in case of these technologies is different. Hopefully, these technologies that have been developed by the scientists from developed countries will be available to any lab including those in the developing countries. These technologies are well developed and can be applied directly to evolve a crop resistant to stresses caused by virus. Besides the all types of biotechnological approaches RNAi is the most important. Besides, CRISPR Cas9 can be a great challenge to RNAi.

\section{References}

Alberts, B., Johnson, A., Lewis, J., Raff, M., Roberts, K. and Walter, P. 2002. Molecular biology of the cell. 4. ed. Garland Science, New York.1463 p.

Ali, Z., Abulfaraj, A., Idris, A., Ali, S., Tashkandi, $M$ and Mahfouz, M.M. 2015. CRISPR/Cas9-mediated viral interference in plants. Journal of General Biology. 16:1238.

Baltes, N.J., Hummel, A.W., Konecna, E., Cegan, R., Bruns, A.N., Bisaro, D.M. and Voytas, D.F. 2015. Conferring resistance to geminiviruses with the CRISPR-Cas prokaryotic immune System. Nature Plants.1: 15-45.

Baulcombe, D. 2004. RNA silencing in plants. Nature.431:356- 63.

Bhaya, D., Davison, M. and Barrangou, R. 2011. CRISPR-Cas systems in bacteria and archaea: versatile small RNAs for adaptive defense and regulation. Annual review of Genetics. 45: 273-297.

Capoor, S.P and Rao, D.G. 1967. Tristeza virus infection of citrus in India. In: Proceedings of the international symposium on subtropical and horticulture, Bangalore, India, pp. 723-736.

Chaparro-Garcia, A., Kamoun, S. and Nekrasov, V. 2015. Boosting plant immunity with CRISPR/Cas. Genome biology. 16: 254264.
Faccioli, G. 2001. Control of Potato viruses using meristem and stem-cutting cultures, thermotherapy and chemotherapy. In: Loebenstein G et al., (ed) Virus and viruslike disease of potatoes and production of seed-potatoes. Kluwer Academic Publishers, Dordrecht, pp. 365-390.

Ferriol, I., Rubio, L., Perez-Panades, J., Carbonell, E.A., Davino, S. and Belliure, B. 2013.Transmissibility of Broad bean wilt virus 1 by aphids: influence of virus accumulation in plants, virus genotype and aphid species. Annual of Applied Biology. 162:71-79.

Grogan, R.G., Welch, J.E. and Bardin R. 1952. Common lettuce mosaic and its control by the use ofMosaic free seed. Phytopathology.42:573-578.

Hannon, G.J., 2002.RNA interference. Nature. 418:244- 251.

Hosokawa, M., Ohishi, K., Sugawara, Y., Hayashi, T. and Yazawa, S. 2004. Rescue of shoot apical meristems of chrysanthemum by culturing on root tips. Plant Cell Reports. 22:443-448.

Jones, R.A.C., Salam, M.U., Maling, T.J., Diggle, A.J. and Thackray, D.J. 2010. Principles of predicting plant virus disease epidemics. Annuals Review of Phytopathology.48:179-203.

Juarez, M., Legua, P., Mengual, C.M., Kassem, M.A., Sempere, R.N., Gomez, P., Truniger, V., Aranda, M.A. 2013. Relative incidence, spatial distribution and genetic diversity of cucurbit viruses in eastern Spain. Annual of Applied Biology. 162:362-370.

Kammen A.V. 1997. Virus-induced gene silencing in infected and transgenic plants.Trends in Plant Science. pp. 409411.

Kooter, J.M., Matzke, M.A. and Meyer, P. 1999. Listening to the silent genes: transgene silencing, gene regulation and pathogen control. Trends in Plant Science.4:340-347.

Kumar, V. and Jain, M. 2014 The CRISPR-Cas system for plant genome editing: advances and opportunities. The Journal of Experimental Botany.66: 47-57

Lippman, Z. and Martienssen, R. 2004. The role of RNA interference in heterochromatic silencing. Nature, 431:364-370. 
Mackie, A.E., McKirdy, S.J., Rodoni, B. and Kumar, S. 2002. Potato spindle tuber viroid eradicated in Western Australia. Australasian Plant Pathology.31:311-312.

Magee, C.J. 1948. Transmission of bunchy top to banana cultivars. The Journal of Australian Institute Agricultural Science. 14:18-24.

Mannan, M.A. 2003. Some aspects of integrated management of potato aphid, Myzus persicae (Sulz.) (Homoptera: Aphididae). Thai Journal of Agricultural Science. 36:97-103.

Mansoor, S., Amin, I., Hussain, M., Zafar, Y. and Briddon, R.W. 2006. Engineering novel traits in plants through RNA interference. Trends in Plant Science.11:559-565.

Melchers, L.S. and Stuiver, M.H. 2000. Novel genes for disease resistance breeding. Current Opinion in CellBiology. 3:147-152.

Neckers, L. and Whitesell, L. 1993. Antisense technology: biological utility and practical consideration. Annual Review of Physiology.265: 1-12.

Qi, L.S., Larson, M.H., Gilbert, L.A., Doudna, J.A., Weissman, J.S., Arkin, A.P. and Lim, W.A. 2013. Repurposing CRISPR as an RNA guided platform for sequence-specific control of gene expression. Cell152:11731183.

Sastry, K.S. 2013. Plant virus and viroid diseases in the tropics. Introduction of plant viruses and sub-viral agents, classification, assessment of loss, transmission and diagnosis. Springer, New York (In Press)
Thomsen, A. 1975. Crop reduction in pear trees caused by virus infection. Acta Horticulturae. 44:119-122.

Thresh, J.M. 2003. Control of plant virus diseases in sub-saharan Africa: the possibility and feasibility of an integrated approach. African Crop Science Journal.11:199-223.

Thresh, J.M. 2006. Control of tropical plant virus diseases. Advances in Virus Research. 67:245-295

Vaucheret, H. and Fagard, M. 2002. Transcriptional gene silencing in plants: targets, inducers and regulators. Trends in Genetics. 17:29-35.

Wang, H., La, R.M. and Qi, L.S. 2016. CRISPR/Cas9 in genome editing and beyond. Annual Review of Biochemistry. 85: 227-264.

Wang, H.L., Yeh, S.D., Chiu, R.I. and Gonsalves, D. 1987. Effectiveness of cross protection by mild mutants of Papaya ring spot virus for control of ring spot disease in Taiwan. Plant Disease. 71:491-497.

Waterhouse, P.M., Wang, M.B. and Lough, T. 2001. Gene silencing as an adaptative defense against viruses. Nature. 411:834842.

Zhang, Ji. X., Zhang, H., Wang, Y. and Gao, C. 2015. Establishing a CRISPR-Cas-like immune system conferring DNA virus resistance in plants. Nature Plants. 1: 35-44.

\section{How to cite this article:}

Sheemal Sugandha Sharma, Shalini Verma and Anil Handa. 2019. Biotechnological Approaches in Management of Viral Diseases of Horticulture Crops. Int.J.Curr.Microbiol.App.Sci. 8(06): 2059-2072. doi: https://doi.org/10.20546/ijcmas.2019.806.246 